\title{
From Wales to Warsaw and Beyond: NATO's Strategic Adaptation to the Russian Resurgence on Europe's Eastern Flank
}

\section{Mariusz Fryc}

National Security Bureau, Warsaw, Poland, http://en.bbn.gov.pl/

\begin{abstract}
The illegal annexation of Crimea in the spring of 2014 changed dramatically security perceptions and increased the anxiety in Eastern Europe even among NATO member states. NATO reacted quickly by adopting the Readiness Action Plan, transforming the NATO Response Force, and deciding to establish command control centers, or NATO Force Integration Units (NFIUs), in six countries on its Eastern flank. In light of the forthcoming Summit in Warsaw, the author reasons that despite such significant security measures, NATO capabilities and actions are still insufficient to adequately face the current level of uncertainty and challenges on the Eastern side of Europe and to reassure its members. This article explores requirements and options in deepening the sense of security of the eastern NATO members who face Russian classical military as well as hybrid threats. The focus is on developing a two prong deterrence strategy - punishment-based and deterrence by denial, strengthening Host Nation Support military infrastructure, streamlining operational decision making by empowering the SACEUR, and intensifying cooperation with the European Union and non-NATO Baltic counties.
\end{abstract}

Keywords: NATO, European Security, hybrid warfare, strategic risk, deterrence, Readiness Action Plan, NFIU, multinational formations.

\section{Introduction}

On March 30, 2016, the Polish minister of defense launched a one-hundred-day countdown that will run until NATO's summit in Warsaw, which will likely have a significant impact on the Alliance's future. At the same time, and in light of Russia's increasingly aggressive resurgent actions targeted at shattering West- 
ern unity, the US administration has decided to send an armored brigade combat team to Europe in February 2017. This team will offer a rotational forward presence and bolster NATO's deterrence, thereby reassuring its members on the eastern flank. Since its last summit in Wales in 2014, NATO has changed its posture significantly, moving away from reassurance. It has strengthened the NATO Response Forces (NRF) and regionally aligned command structures, stepped up its exercises and training sessions, and even decided to bulk up its military presence through the establishment of a rotational, multinational brigade-sized component.

Unfortunately, these security measures have not yet gone far enough to meet the expectations of the Baltic states and Poland. In view of the provocative actions of the Russian Federation, they are calling for a stronger NATO presence, achieved through the creation of permanent military bases on their territories. For these nations, the upcoming NATO summit, due to take place on July 8-9, 2016, will likely only bring dissatisfaction in its wake. This particular Alliance-internal disagreement raises a range of relevant questions in terms of the extent to which NATO has been able to adapt on a strategic level to the new security environment, which was primarily changed by Russia as a result of its illegal annexation of Ukrainian Crimea. Questions will also be posed as to what NATO should do next to reinforce a sense of security among its eastern members, who are faced with both classic military threats and the risk of hybrid attacks.

\section{Russia's Hybrid Warfare with Ukraine and the West}

With the annexation of Crimea in March 2014, Russia launched its neo-imperialist mission and attempt to position itself globally as one of the world's unquestioned superpowers. Moscow unleashed its hybrid military beast on Ukraine and the West, perceiving the Western world as its key opponent, the former Soviet bloc as a crucial sphere of influence, and NATO as a strategic national security threat.

Russia exploited Ukraine's weaknesses, namely its transatlantic relationship and solidarity as the center of gravity of Western power, and launched an assault on morale, physical might, and freedom of action. Russia pulled out all the stops, seeking a strategic victory via the use of both material and immaterial, military and non-military, legal and illegal, and direct and indirect onslaughts on the West and Kyiv. This objective was reached without the overt application of substantial military force.

Exploiting institutional weak spots and legal pressure points, historical and ethnic tensions, as well as financial and business opportunities, Russia's hybrid strategy was not only successful in Ukraine, but also had influence on the international level. This influence was also directed at Russia's own population, with the aim of consolidating the Kremlin's power and providing it with national legitimacy for unrestricted policies and action. While ensuring that the warfare was kept simmering below the boiling point of conventional war, Mos- 
cow advanced both kinetic and non-kinetic lines of operation, wearing down its enemy not through a decisive battle in the classic, Clausewitzian military sense, but rather through the attrition of morale. Non-kinetic efforts include political indoctrination, siege tactics, conspiracy theories tinged with anti-Semitism, the labeling of individuals as "Nazis," the exploitation of the diaspora, and the influence of the Orthodox Church. This uncompromising information struggle saw Moscow exploit the influence of state media, online "troll armies," proKremlin extremist narratives from political movements, think tanks, anti-globalist groups, and even various NGOs.

In the economic domain, Russia began to conduct financial warfare in the form of currency speculation and the destabilization of monetary systems, as well as trade warfare by blackmailing companies and energy providers and manipulating energy prices. In the cyber sphere, Moscow continued its cyber-attacks against critical public and private infrastructure networks, as well as cyberespionage activities.

The Kremlin's kinetic actions had been achieved by executing direct military deterrence tactics, including the massing of large conventional forces along the eastern border with Ukraine; conducting aggressive and provocative aviation incursions into European airspace (the Baltics, Sweden, Finland, Poland); threatening to use weapons of mass destruction (deployment of nuclear weapons in Crimea); organizing "snap" ground exercises on a large scale or military inspections without notice; continuously providing information about plans to deploy new weapons systems to the areas bordering NATO member states (e.g. deployment of Iskander-the mobile short-range ballistic missile system capable to carry nuclear warheads - to Kaliningrad Oblast) or about ambitious plans to modernize the armed forces.

Indirectly, Moscow had deployed covert "paramilitary proxies," dubbed "little green men" (Russian military personnel operating without insignia and official affiliation), to assist pro-Russian separatists, act as a diversion, apply sabotage or even terrorist tactics, as well as provide them with heavy military equipment - tanks, self-propelled artillery, and air defense systems.

\section{European Security Context Following Russia's Illegal Annexation of Crimea}

Russia's blitzkrieg annexation of Crimea and the subsequent surge in pro-Russian separatists in south-east Ukraine, provoked and backed by Moscow, shook the foundations of the post-Cold War security environment in Europe. Its open show of force caught the Western community and NATO by surprise, and put NATO's eastern European members in a vulnerable position.

Moscow's hybrid strategy enables it to achieve its strategic objectives by using all available means of power and engaging both regular and non-regular troops on a limited scale and in an indirect manner, thus keeping its actions below the threshold of international war, and below the threshold required to provoke a NATO response. The risks associated with this kind of strategy gave 
eastern European nations real cause for concern. In their view, this particular non-linear approach would be very problematic in terms of a NATO response, the crux of which would be reaching a political-military consensus among the Alliance in terms of how to respond collectively to such a threat, if necessary. They also believed that the consequences of a failure to do so, in the worstcase scenario, might lead to the undermining of NATO's Article 5.

Security concerns to which NATO members on the Alliance's eastern flank were exposed resulted in the strengthening of the Alliance's air-policing mission and deployments of US rotational land and special operations forces to the Baltics and Poland. Thanks to this commitment NATO was able to increase interoperability through training sessions and exercises, demonstrate persistent US military commitment, and show its adherence to Article 5 of the Washington Treaty. ${ }^{1}$

Despite this incontrovertible sign of solidarity among NATO members, the security situation failed to improve. This led to the uncovering of a series of discrepancies in terms of national attitudes, policies, and approaches vis-à-vis Russia's unpredictability. Russia continued to apply the pressure in the form of its hybrid offensive, and even divisions between Europeans began to show. Fault lines also started to appear across key geopolitical platforms such as the Visegrad Group and the Weimar Triangle. In some cases, the Western states' reluctance to oppose Russia's non-linear actions, as well as their inclination to focus on reassuring their own domestic interests, especially from an economic perspective, started eating away at Europe's solidarity and strength. Importantly, the new security context once again revealed Europe's military weakness and inability to reassure its members without US-backed military support. This also reinforced the desire of those NATO members on the eastern flank for a significant and permanent US military presence in their territories.

The West finally managed to impose diplomatic, economic, and financial sanctions on Moscow in July 2014 in response to Russia's seizure of Crimea. These sanctions were tightened in December $2014 .^{2}$ Sanctions began to contribute to the overarching policy aim of containing Russia's behavior, with the objective of imposing sufficient costs to Russia's economy while at the same time limiting any negative macroeconomic effects on the US and Europe. ${ }^{3}$ Unfortunately, all diplomatic solutions intending to bring peace to eastern

1 Senate Armed Services Committee, Statement of General Philip Breedlove, Commander U.S. Forces Europe, April 30, 2015, accessed July 17, 2016, http://www.armed-services.senate.gov/imo/media/doc/Breedlove_04-30-15.pdf. Robin Emmott and Dmitry Solovyov, "EU urges more countries to impose sanctions on Russia over Crimea," Reuters, March 18, 2016, accessed July 17, 2016, http://www.reuters.com/article/us-ukraine-crisis-eu-crimea-idUSKCNOWK167.

3 "Remarks of Secretary Lew on the Evolution of Sanctions \& Lessons for the Future at the Carnegie Endowment for International Peace," United States Mission to the European Union, March 30, 2016, accessed July 17, 2016, http://useu.usmission.gov/ speech33016.html. 
Ukraine proved to be insufficient. The Minsk Protocol of September 2014, for example, signed by Kyiv authorities and pro-Russian separatists, stipulates the implementation of a ceasefire and the establishment of a demilitarized buffer zone but was flawed from the start. In Newport, Wales, also in September 2014, NATO resolved to make substantial changes to its posture, modus operandi, and force structure to ensure that it would be able to face new security challenges effectively and relieve its member states in Eastern Europe of their defense concerns.

\section{NATO's Strategic Adaptation: From Reassurance to a Deterrence Posture}

The summit saw the announcement of a Readiness Action Plan (RAP), which details the implementation of necessary security and defense measures. This comprehensive package is divided into assurance and adaptation measures ${ }^{4}$ with the objective of reinforcing the Alliance's presence and military activity in Eastern Europe and introducing substantial long-term changes to NATO's force posture, enabling it to respond more quickly to future challenges and threats. ${ }^{5}$ Further, the package calls for the fundamental reconstruction of the NRF. To make its forces more responsive and capable, the Alliance decided to set up a new rapid response "spearhead force": the Very High Readiness Joint Task Force (VITF), with forward-deployed multinational commands (NATO Force Integration Units [NFIUs]) that enable forces to be activated and deployed across the territories of NATO's eastern members. It was presumed that the VJTF would be formed as a brigade-sized combat group consisting of several thousand soldiers, including a substantial land component backed by air, maritime, and special forces units. It would consist of three to five maneuver battalions and remain ready for action at five or seven days' notice. One of its battalions, consisting of approximately 650 soldiers, would be ready to deploy within two to three days' notice. NFIUs would handle the synchronization and reception of the VJTF in eastern European territories. Aside from these duties, each NFIU would also be charged with coordinating exercises and joint planning. To ensure adequate host nation support (HNS) post-deployment, NATO decided to improve pre-positioning infrastructure, such as airfields, ports, and specific bases to ensure the reception of the VJTF and NRF runs smoothly.

The adaptation measure also encompasses raising the readiness level of the Multinational Corps North East (MNC NE) headquarters in Szczecin (Poland), as well as enhancing its role in potential NATO operations on the eastern flank. Finally, NATO members decided to update contingency plans for Eastern Europe. They also agreed to halt cuts in defense spending and gradually increase it to

\footnotetext{
4 "NATO's Readiness Action Plan," Fact Sheet, May 2015, accessed July 17, 2016, http://www.nato.int/nato_static_fl2014/assets/pdf/pdf_2015_05/20150508_1505Factsheet-RAP-en.pdf.

5 Ibid.
} 
the expected 2 percent of GDP over the next decade. All the countermeasures undertaken served to emphasize the desire to strengthen not only NATO's collective defense capabilities, but also its crisis management mechanism.

The implementation of the assurance measures involved the Alliance maintaining an increased number of fighter jets on air-policing patrols over the Baltic states and deploying fighter jets to Poland and Romania. Simultaneously, along NATO's eastern borders, an Airborne Warning and Control System (AWACS) continued regular surveillance missions. Intensified maritime forces started patrolling the Baltic, Black, and Mediterranean Sea. Following the implementation of the assurance measure, by late 2014 NATO had stepped up its crisis management strategy and its collective defense training sessions and exercises. In the meantime, initiatives conducted both by individual states and on a joint-state basis also started to contribute to NATO's assurance package. The US provided significant support in this area. Its European Reassurance Initiative (ERI) was designed to reassure NATO members as well as other non-NATO partners that felt most threatened by Russia's actions. The initiative includes increasing US military presence in the region, invigorating bilateral and multilateral exercises and training sessions, improving the necessary infrastructure, enhancing the pre-positioning of US equipment, and intensifying efforts to build up partner capacity. ${ }^{6}$ In December 2014, the US Congress approved funds amounting to $\$ 810$ million for the program, as well as an additional $\$ 175 \mathrm{mil}-$ lion for the provision of military assistance to Ukraine and the Baltic states. ${ }^{7}$ By 2015, NATO established the interim VJTF. Led by Germany, the Netherlands, Norway, and supported by other Allies, it was put through a series of exercises and evaluations.

In January and February 2015, the Allies refined the overarching VJTF concept. In April and June 2015, during an exercise dubbed "Noble Jump," NATO evaluated the VJTF's ability to deploy at short notice in response to an evolving crisis. Then, in October and November 2015 during maneuvers nicknamed "Trident Juncture," the Allies demonstrated the VJTF's capacity to deploy within a matter of days from across the Alliance.

Despite the fact that NATO was vigorously implementing both assurance and adaptation countermeasures, a lack of significant security improvements in the Baltic region forced the military authorities of Lithuania, Latvia, and Estonia to request in May 2015 that SACEUR establish a rotational, brigade-sized combat unit on their territories as a deterrence force against Russia. Although a formal decision was been taken, in June 2015 NATO defense ministers decided to beef up the NRF, now totaling forty thousand as opposed to the previous thirteen thousand. Furthermore, they granted SACEUR new powers to prepare forces in advance that could be deployed in the event of a potential crisis, fur-

6 European Reassurance Initiative - Department of Defense Budget Fiscal Year (FY) 2016, February 2015, accessed July 17, 2016, http://comptroller.defense.gov/ Portals/45/Documents/defbudget/fy2016/FY2016_ERI_J-Book.pdf.

7

Ibid. 
ther maximizing its responsiveness. Finally, they directed the MNC NE to reach full operational capability as a high-readiness headquarters by the next NATO summit as well as to be able to coordinate the NFIU's functions and command the VJTF.

By September 2015, all six new NFIUs were active with the aim of reaching operational status prior to the summit in Warsaw. The Joint Force Command (JFC) Naples took operational control of NFIUs established in Bucharest and Sofia, while the NFIUs in Riga, Tallinn, Vilnius and Bydgoszcz were subordinated to MNC NE.

In December 2015, the US Army started moving sets of equipment, known as the European Activity Sets (EAS), to the first forward-positioned sites in Bulgaria, Romania, and Lithuania. The equipment, used by the army's regionally aligned force for the purpose of training and exercises with Allies under Operation Atlantic Resolve, is ultimately to be stored in seven locations across Eastern Europe. ${ }^{8}$

Also in December 2015, due to the expansion of Russia's military potential in the Black Sea region as well as the militarization of annexed Crimea, NATO set up the Multinational Division Southeast (MND SE) headquarters in Romania. This addition is designed to facilitate the command of Allied forces deployed in the southeastern part of Europe.

The meeting of NATO defense ministers of February 2016 resulted in additional reinforcements to the Alliance's eastern flank. They decided to beef up military presence in the area through the establishment of a multinational force rotation. There was little desire to have forces stationed there on a permanent basis, and NATO military planners started calculating the size and composition of troops required, as well as how to rotate them in and out of the Eastern European members' territories. ${ }^{9}$

These NATO ministerial decisions followed an announcement by the US administration a week prior that revealed plans to increase spending on the ERI to a level four times higher than that of 2016, pending the approval of the $\$ 3.4$ billion defense budget for the fiscal year of $2017 .{ }^{10}$ If approved, an increase in troop rotations and military exercises in Europe will follow, due to the fact that approximately $\$ 2.8$ billion of the budget is to be allocated to the US Army in

8 "Tanks, heavy vehicles to be fully positioned in Eastern Europe next year," Stars and Stripes, December 10, 2015, accessed July 17, 2016, http://www.stripes.com/news/ europe/tanks-heavy-vehicles-to-be-fully-positioned-in-eastern-europe-next-year1.383125 .

9 "NATO ministers approve new reinforcements for eastern Europe," MailOnline, February 10, 2016, accessed July 19, 2016, http://www.dailymail.co.uk/wires/ap/ article-3440315/NATO-chief-expects-OK-greater-forward-presence.html.

$10 \mathrm{Jim}$ Garamone, "Gorenc Discusses European Reassurance Initiative, Air Police Mission," U.S. Department of Defense, April 5, 2015, accessed July 17, 2016, http://www.defense.gov/News-Article-View/Article/713722/gorenc-discusseseuropean-reassurance-initiative-air-police-mission. 
Europe. ${ }^{11}$ With these funds the Army plans to deploy an additional rotational armored brigade combat team on the European stage in February 2017, and reinforce pre-positioned stocks to ensure one set of combat-ready equipment is available to support another armored brigade, if deployed, as well as division-level enablers. ${ }^{12}$ By the end of 2017, the US Army plans to have a continuous presence of three fully-equipped army brigade combat teams in Europe. ${ }^{13}$

The reassurance and adaptation measures put into place have significantly contributed to assuaging NATO's Eastern European members. The expanded NATO exercises carried out throughout the course of $2015^{14}$ have had the expected effect and are to be continued throughout 2016. NATO's primary reaction tool, the NRF has seen substantial improvement. Comprising three separate elements, NRF was strengthened by the establishment of the very highreadiness joint force at its core, which enabled it to leverage its responsiveness and reach peak swiftness and operational agility. The VJTF concept is to be tested through a number of exercises throughout 2016 to reach its full operational status, such as "Brilliant Jump," "Trident Joust" and "Brilliant Capability." "15 "Brilliant Jump" will be the final VJTF examination directly prior to the NATO summit. Its operational status must be demonstrated through the deployment of force in NATO's eastern member states.

As soon as the first indication of a crisis reveals itself, the NRF, supported by a network of new headquarters (MNC NE, MND SE, NFIUs) spread across the eastern Alliance territories, will be able to deploy and engage troops quickly to fulfill the collective defense mission. ${ }^{16}$ By 2018, MNC NE will be able to command the NRF and lead combined defensive operations on a large scale on the

11 Senate Armed Services Committee, Statement of General Philip Breedlove, Commander U.S. Forces Europe, March 1, 2016, http://www.armed-services.senate.gov/ $\mathrm{imo/media/doc/Breedlove \_ 03-01-16.pdf.}$

12 "Eucom announces European reassurance initiative implementation plan," Eucom Live, March 30, 2016, accessed July 17, 2016, http://eucom.dodlive.mil/2016/03/ eucom-announces-european-reassurance-initiative-implementation-plan/.

13 Two of them are already permanently stationed in Western Europe (a Stryker brigade and an Airborne brigade).

14 Major exercises in 2015 include: Joint Warrior (11-23 April: naval exercise in the North Atlantic, 13,000 troops); Dynamic Mongoose (4-15 May: antisubmarine warfare exercise off Norway, 5,000 troops); Baltops (5-20 June: naval and amphibious exercise in the Baltic Sea, 4,500 troops); Sabre Strike (8-19 June: land exercise in the Baltic states and Poland, 3,000 troops); Noble Jump (10-21 June: first deployment test for the new high readiness force to Poland, 2,100 troops); Trident Joust (17-28 June: headquarter exercise in Bulgaria, Romania and Italy, 1,500 troops) and Trident Juncture (21 October-6 November: Italy, Portugal and Spain, 25,000 troops). Cf. "NATO's Readiness Action Plan. Fact Sheet."

15 "NATO Response Force (NRF) Fact Sheet," accessed July 17, 2016, https://jfcbs.nato.int/page5725819/nato-response-force-nrf-fact-sheet.

16 “Projecting Stability: Charting NATO's Future. Speech by NATO Secretary General Jens Stoltenberg to the Atlantic Council, Washington, D.C.," April 6, 2016, accessed July 17, 2016, http://www.nato.int/cps/en/natohq/opinions_129758.htm. 
Alliance's northeastern flank. All six NFIUs are expected to achieve a fully operational status shortly prior to the upcoming NATO summit. ${ }^{17}$ Subsequently, two additional NFIUs are to be set up in Slovakia (2016) and Hungary (2017). ${ }^{18}$ Decisions regarding the forces to be subordinated to the MND SE are to be taken following the Warsaw Summit. ${ }^{19}$ The command is expected to reach initial operational capabilities in 2016, and full operational capabilities in 2018. Sites in Poland, Estonia, and Latvia, as part of the EAS concept, are expected to be available in 2016, supplemented by an additional location in Hungary in $2017 . .^{20}$

All these actions and countermeasures implemented by NATO have managed, to some extent, to repair the unity and solidarity of the Alliance and significantly reassure its vulnerable eastern members in the face of Russia's potential classic military threats and hybrid actions. However, as long as Russia follows its neo-imperialist strategy and tests NATO's credibility, the main concerns of NATO's eastern member states, particularly those in the Baltics, remain only partially allayed.

\section{Russia's Response to NATO's Strategic Adaptation}

All the actions undertaken by NATO to reassure its eastern Allies are perceived by Moscow as NATO's "expansion by stealth" into Eastern Europe: an expansion that has to be stopped. As a result, the security situation in that region is still predominantly determined and shaped by Russia's attitudes and actions, which are highly uncertain and unpredictable. The Kremlin continues to employ a non-linear, hybrid strategy that, to some extent, seems to be an antithesis to the comprehensive approach to military operations as used by the West. While using all available methods of force (political, economic, military, information, etc.), Moscow maintains a level of tension/aggression below the threshold of war by engaging troops as a deterrence tool or on a limited scale and in an indirect manner, allowing Russia to achieve its strategic objectives. Russia further threatens and intimidates the international community by implication, provoking and escalating tensions not only in Eastern Europe but across the world, and importantly, constantly manipulating international public opinion by ascribing responsibility for the effects of its actions to the West.

Despite the county's deteriorating economic situation, the effect of longterm Western sanctions and a decline in oil and gas prices, a strong political determination to strengthen its military potential and to improve its combat responsiveness and readiness is still visible. The Russian air force continues to

17 NATO Force Integration Units (NFIU), accessed July 17, 2016, https://jfcbs.nato.int/ page5725819/nato-force-integration-units.

18 "NATO Response Force (NRF) Fact Sheet."

19 Tadeusz Wróbel, “Sojusz w Bukareszcie," Polska Zbrojna.pl, December 10, 2015, accessed July 17, 2016, http://www.polska-zbrojna.pl/home/articleshow/17942?t= Sojusz-w-Bukareszcie.

20 "Tanks, heavy vehicles." 
routinely violate the airspace of sovereign states on the eastern and southern flank of the Alliance, which leads to unnecessary incidents, even provoking international crises and bringing with it a significant risk of open confrontation, as occurred in November 2015 when Turkey shot down a Russian warplane.

In Kaliningrad Oblast, for instance, Russia has managed to expand its offensive anti-access/area-denial (A2/AD), and also expeditionary, potential. ${ }^{21}$ This allows Moscow to hamper any Allied air and naval access there, restrict Allied freedom of movement, and even cut off the Baltic states from NATO's support by blocking the sole land supply route from Poland, namely the "Suwałki Gap." Limiting the counteroffensive military capabilities of the Baltic states has allowed Moscow to maneuver itself into a position from which it could potentially execute a rapid seizure of the territory with the use of approximately twenty-two battalions from the Western Military District and Kaliningrad. ${ }^{22}$ Such a scenario may force NATO into a position whereby it is required to conduct a very difficult, costly, and time-consuming strategic counteroffensive operation.

Moscow is deliberately keeping the conflict in eastern Ukraine in a frozen state, where it escalates and deescalates tensions there at will. After a relatively calm period in early 2016, the significant military activity in Donbas has increased again. ${ }^{23}$ Russia is still supporting the separatists with command and control, fire support, unmanned aerial vehicles (UAVs), communications assistance, and surface-to-air missile systems. ${ }^{24}$ By keeping the territories occupied by pro-Russian separatists in a permanent state of uncertainty, Moscow is able to maintain the strategic maneuverability necessary to exert pressure on Kyiv and the West.

According to NATO's SACEUR, Russia has been deliberately using the flood of Syrian refugees to destabilize Europe and deplete its instruments of humanitarian aid and social care. Russia's entry into the Syrian conflict has substantially changed the dynamic of the war, causing a displacement of more than half a million Syrians since September 2015. The refugee crisis is expected to escalate further, likely destabilizing the security environment in Turkey, the Eu-

${ }^{21}$ A2/AD capabilities include the most advanced air defense mobile systems (S-400 Triumf / SA-21 Growler with an operational range of up to $400 \mathrm{~km}$ ) and dual-capable (classic and nuclear) mobile short-range ballistic missile systems (Iskander-M / SS-26 Stone with an operation range of up to $500 \mathrm{~km}$ ).

22 According to a report published by the RAND Corporation, getting to Riga or Tallinn would take Russian forces 36 to 60 hours. Cf. David A. Shlapak and Michael V. Johnson, Reinforcing Deterrence on Nato's Eastern Flank (RAND Corporation, 2016), accessed July 17, 2016, http://www.rand.org/content/dam/rand/pubs/research_ reports/RR1200/RR1253/RAND_RR1253.pdf.

"Department of Defense Press Briefing by Gen. Breedlove in the Pentagon Briefing Room," U.S. Department of Defense, March 1, 2016, accessed July 17, 2016, http://www.defense.gov/News/News-Trans/Tran-View/Article/683817/departmentIbid. 
ropean Union, and NATO even more. However, the crisis will also enable Russia to consolidate its influence on the West and leverage its position for negotiations in the future.

In 2016, Russia plans to increase its military potential and posture still further. Due to the dynamically changing and uncertain situation in its close vicinity, Moscow intends to implement significant defensive countermeasures. Moscow wants to beef up its nuclear deterrence posture by installing new "nuclear triad" systems and improving the effectiveness of its warning system against missile attacks. Over 95 percent of all nuclear forces are to be held in a state of constant combat readiness. The number of intercontinental ballistic missile tests will be doubled to sixteen attempts, compared to eight tests in 2015.

One area of high priority reinforcement is the combat troops operating in the Western, Southwestern and Arctic Military District. Land forces are to form four additional divisions, based on existing brigades. Three of them are likely to be set up in the Western Military District, and one in the central area. Meanwhile, unannounced inspections will be held to check the combat readiness of all military districts, military services and branches. Air defense readiness is obliged to maintain the highest priority level. The essential maneuver for the Russian armed forces will be the "Caucasus 2016" strategic exercise, due to take place in September 2016. It will play out in the Southern Military District, North Caucasia and Crimea. The main focus will be on the creation of a large formation of troops and their deployment over long distances. Operational readiness and responsiveness has been granted "high priority" status. Allegedly, Russian General Staff have laid down the gauntlet and requested that sixty-five thousand troops are to be moved over a distance of three thousand kilometers in seventy-two hours.

In 2016, Moscow will also continue an intensive technical modernization of its armed forces. The modern equipment is to constitute 51 percent of the overall set and the level of its efficiency is to reach 92 percent. It is expected to put in service two brigade missile sets (Iskander-M and Tornado-C), one brigade air-defense complex (Buk-M3), and re-arm six battalions with new tanks and infantry combat vehicles. Airspace forces are to receive two hundred new and modernized types of aircraft and five air-defense regiments will be rearmed with S-400 systems. The navy will be provided with two new multi-purpose submarines and seven surface warships. With an intensive modernization drive on this scale, Moscow wants to position the military-industrial complex as the engine of its entire national economy and transportation infrastructure.

Year after year, public support continues to grow for the Kremlin's continuing anti-Western policy. As surveys of the Russian public show, a growing number of individuals still support an increase in defense spending, even if this comes at the cost of weakening the country's economic condition. In 2013, support for this amounted to 46 percent, while in 2015, this rose to 53 percent. This trend is unlikely to reverse as long as the impact of Russia's information 
policy towards its own people remains in place with the same scope and at the same level of intensity.

\section{Potential Improvements to NATO's Eastern Flank}

NATO's journey from the Wales Summit to the Warsaw Summit has been long and arduous. The Alliance initially adapted to the new security environment with a policing mission, subsequently adopting a reassurance posture, and finally settling on a deterrence posture. Due to the implementation of a series of effective reassurance and adaptation measures, NATO has become more politically united, military agile and responsive, and, last but not least, persuasive as a whole. Almost all the strategic goals established in Wales have been met or are on the cusp of concluding their timelines in the run-up to the next NATO Summit in Warsaw.

However, despite the significant achievements mentioned above, NATO must continue with its strategic adaptation to be able to face all future challenges, whether classic or hybrid, with success. There are still a number of ways in which NATO could enhance its reassurance and deterrence posture on the eastern flank of the Alliance. Below are twelve broad-brush methods that are worthy of reflection and implementation.

\section{Leveraging Internal Solidarity and Strategic Empathy}

Until the annexation of Crimea, European allies suffered as a result of a serious lack of strategic consensus in terms of the extent to which NATO should be focused on territorial defense, and to what degree these nations are to assign their resources to expeditionary operations. Due to Russia's actions, the perspective of NATO members is now somewhat united, though there are still differences with regard to how strategic issues are perceived, notably how to handle Russia. These differences are noticeable not only at the level of government, but also among the public in western NATO states. In a survey of public opinion conducted last year, 58 percent of German, 53 percent of French and 51 percent of Italian respondents were against sending their soldiers to defend NATO members such as Poland or the Baltic states if they were attacked by Russia. This trend in terms of general public opinion is not likely to change. ${ }^{25}$ NATO's lack of a consistent strategy towards Russia will presumably have as a result that the Warsaw Summit sees the Allies not reaching the conclusion the Eastern European members want and expect, namely the establishment of permanent military bases on their territories. ${ }^{26}$ This challenge calls for the members states to leverage internal solidarity and strategic empathy so

25 Frayed Partnership. German public opinion on Russia (Gütersloh: Bertelsmann Stiftung, 2016), accessed July 17, 2016, http://www.bertelsmann-stiftung.de/ fileadmin/files/user_upload/EZ_Frayed_Partnership_2016_ENG.pdf.

26 Judy Dempsey, "Judy Asks: Is NATO Doing Enough in Europe?" Judy Dempsey's Strategic Europe, March 23, 2016, http://carnegieeurope.eu/strategiceurope/ ?fa $=63093$. 
that they can understand each other better. Western European nations must try to understand the perspective of the member states on the eastern flank, and come to grips with their rhetoric of these states as a "buffer zone" or NATO's strategic depth.

\section{Developing a Two-pronged Deterrence Strategy}

To offer eastern NATO members more reassurance, the Alliance should develop a two-pronged deterrence strategy. First up: a punishment-based strategy, reactive by nature, and functioning on the premise that the West/NATO will be able to defeat an adversary with a devastating counterattack, including the potential of nuclear response. Hot on its heels: deterrence by denial, proactive from the start, seeking to make it physically harder for an opponent to attack by making the overall costs of continuing higher than the predicted gains. ${ }^{27}$

The use of NATO's nuclear posture as a central factor in an Allied punishment-based deterrence strategy needs to be rethought and updated. Russian national security strategy, as it stands in 2015 , does not mention a preemptive nuclear strike. It only suggests applying this force in retaliation for an attack against Russia or its allies with nuclear weapons or other weapons of mass destruction (WMD), or in the event of conventional aggression that might endanger the existence of the state itself. However, at present Moscow is making increasing use of its nuclear posture as a way to get its message across. NATO flank members are faced with nuclear-capable bombers (TU-95) flying close to their borders. They are being informed about the deployment of a nuclear-capable tactical missile (Iskander) to Kaliningrad Oblast or about nuclear elements to conventional exercises in the Baltic region. ${ }^{28}$ These intimidation tactics need to be evaluated as part of NATO's nuclear doctrine.

Furthermore, since 2014, the US has been raising concerns about Russia's compliance with the Intermediate-Range Nuclear Forces (INF) Treaty. ${ }^{29}$ There is a risk that Russian cruise missiles meet the definition given in the INF Treaty of

27 A. Wess Mitchell, "A Bold New Baltic Strategy for NATO," The National Interest, January 6, 2016, accessed July 17, 2016, http://nationalinterest.org/feature/bold-newbaltic-strategy-nato-14818?page=3.

28 Michal Baranowski and Bruno Lété, NATO in a World of Disorder: Making the Alliance Ready for Warsaw (Washington, DC: The German Marshall fund of the United States, 2016), 10; http://www.gmfus.org/publications/nato-world-disorder-making-allianceready-warsaw.

29 The United States and Soviet Union signed the INF Treaty in December 1987. They agreed that they would prohibit all land-based ballistic and cruise missiles with ranges between 500 and 5,500 kilometers. This agreement would apply to missiles with nuclear or conventional warheads, but not to sea-based or air-delivered missiles. Cf. Amy F. Woolf, Russian Compliance with the Intermediate Range Nuclear Forces (INF) Treaty: Background and Issues for Congress (Washington DC: Congressional Research Service, 2016), accessed July 17, 2016, https://www.fas.org/sgp/crs/ nuke/R43832.pdf. 
a ground-launched cruise missile with a range capability of five hundred kilometers to 5,500 kilometers, and as such, all missiles of this type, as well as all launchers for the missiles, are prohibited under the provisions of the agreement. Although Russia denies a violation of this nature, NATO must draw up a course of action detailing how to respond if Russia withdraws from the INF Treaty and deploys new INF missiles that would enable it to target or threaten most of NATO's European members.

Deterrence by denial includes embracing a sizable force presence, an A2/AD concept and capabilities, as well as a long-term resistance approach prioritizing a territorial defense mindset, strategy, capabilities, structure, and forces. This particular method should be adapted and kept up to standard by NATO countries on the eastern flank that are facing Russia's aggressive policy. There should be the intention to form four new divisions to achieve the ability to conduct intensive military operations on a large scale on NATO's eastern flank, as well as offer a permanent improvement in terms of A2/AD capabilities in a heavily militarized Kaliningrad Oblast. ${ }^{30}$ The process of developing a new strategy should culminate in the revision or update of NATO's Strategic Concept. Changes should reflect NATO's doctrine and amend its contingency plans accordingly, and clarify NATO's defense plans.

\section{Beefing up Ground Forces in the Baltic Region}

It is in the Baltic Sea region that NATO's existence as a whole is most at risk. Any potential conflict with Russia in the region would leave the West/NATO with a strategic dilemma: risk a war on a large scale with a nuclear power, or lose credibility. ${ }^{31}$ NATO has increased its military presence on the Alliance's eastern flank through the establishment of a multinational rotational force in the form of an armored brigade of between three to five thousand soldiers, and has thus suggestively contributed to deference posture. However, this solution does not offer significant alterations to the unfavorable ratio of Alliance forces in the northeastern part of NATO. Bearing in mind that SACEUR considers the overwhelming force benchmark in that region to be ten-to-one for Rus$\mathrm{sia}^{32}$ the rotational NATO brigade at its current security status seems insuffi-

30 Major Russian units in the Kaliningrad Oblast (part of the Russian Western Military District) are: Baltic Fleet (56 ships, including 2 Kilo-class and 1 Lada-class submarines, as well as 3 frigates, 2 destroyers, 26 corvettes, 9 landing ships and 12 minesweepers), 336th Naval Infantry Brigade, 398th Independent Air Transport Squadron (An-2, An-12, An-24, An-26, Be-12, Mi-8); 689th Independent Naval Fighter Aviation Regiment (Su-27); 4th Independent Assault Aviation Regiment (Su-24); 125th Independent Helicopter Squadron (Mi-8, Mi-12); 396th Independent Shipborne Anti-Submarine Helicopter Squadron (Ka-27); 79th Motorized Rifle Brigade, 7th Motorized Rifle Regiment, 183rd Fleet Ground Forces Rocket Regiment, 244th Artillery Brigade; 152th Missile Brigade.

31

32 Baranowski and Lété, NATO in a World of Disorder. Ibid. 
cient to offer adequate deterrence and has to be perceived as a temporary answer that needs to be gradually reinforced after the Warsaw Summit.

European NATO members must also realize that although the US has sent additional brigade combat teams to Europe, this is not a marker that its security policy towards Europe has changed. Its strategy still revolves around a limited, rotational forward presence and is based on strategic deployment from the American continent in the event of a conflict. ${ }^{33}$ It should be also recognized that ERI is funded through the annual budget allocated for conducting US operations abroad, not a permanent budget. This means that ERI is not a long-term solution to the issues in Eastern Europe. Rather, it offers a temporary fix that may fluctuate over time and shift to account for the strategic security context. The US has also called on NATO's eastern members to do more to secure themselves.

The strategic imbalance of power in the Baltic region raises a persistent risk that a lack of substantial troop presence as well as the absence of necessary defense capabilities and military installations will likely provoke Russia to test NATO's credibility even further. Thereafter, if NATO members want to establish credible deterrence at a level able to discourage potential adversaries, they should opt to deploy at least two rotational combat-ready brigade-sized components-one in the Baltics and one in Poland close to the recognized weakness of the "Suwałki Gap" ${ }^{34}$ - with long-term plans to have at least one brigade permanently stationed in the Baltics.

\section{Setting Up Air Dominance in NATO's Northeastern Corner}

In light of Russia's robust A2/AD capabilities in the Baltic region, NATO has had to shift the focus of its air doctrine from an air policing concept to that of comprehensive air defense. To preserve its air dominancy, it has to rebuild air defense to include a multi-layered, medium-range, and fully integrated system with air combat components, surface-to-air components, intelligence, surveillance, and reconnaissance systems, as well as airspace assets. ${ }^{35}$ This will enable NATO to conduct high-velocity operations ${ }^{36}$ and provide sufficient air support to forces on the ground as well. To meet this objective, Baltic nations will have to intensify cooperation and modernization processes on an individual level by acquiring air and missile defense assets. On a NATO level, they will also have to

33 Artur Kacprzyk, "USA mobilizuje NATO do wzmocnienia wschodniej flanki," Polska Zbrojna, February 17, 2016, accessed July 17, 2016, www.polska-zbrojna.pl/home/ articleshow/18509?t=USA-mobilizuje-NATO-do-wzmocnienia-wschodniej-flanki.

34 Baranowski and Lété, NATO in a World of Disorder.

35 Jim Garamone, "Gorenc Discusses European Reassurance Initiative, Air Police Mission," U.S. Department of Defense, April 5, 2016, accessed July 17, 2016, www.defense.gov/News-Article-View/Article/713722/gorenc-discusses-europeanreassurance-initiative-air-police-mission.

36 Ibid. 
actively participate in "smart defense programs" like the NATO Missile Defense, Alliance Ground Surveillance, or NATO Air Policing programs.

\section{Strengthen Host Nation Support for Military Infrastructure}

NATO members on the eastern flank must step up their efforts to improve the infrastructure required to secure the sustainability of positioning Alliance forces on eastern NATO nations' territories in the long-term, as well as the protection of the smooth flow of reinforcements for pre-positioned forces in the region. ${ }^{37}$ These members need to invest in HNS capabilities, military installations including ports of aerial and sea debarkation, depots, and other facilities needed for the basing and sustaining of troops and their training.

\section{Granting Authorization to Conduct No-notice NATO Exercises}

Although the Alliance has intensified the exercises it carries out, the NATO-Russia "exercise gap" still remains as far as scale and speed are concerned. In February 2014, just before the annexation of Crimea, Russia mobilized 150,000 troops under the pretext of an anti-terror exercise. Many of the units were then deployed along Ukraine's border just as Russia started its invasion of Crimea. In September, as part of a Vostok-14 exercise, Russia engaged 155,000 troops. At same time, NATO's largest exercises, Anakonda-14 (October) and Bold Alligator-14 (October-November), saw the participation of 13,250 troops and 15,000 troops respectively. This asymmetric status should be neutralized by keeping military exercises on the highest relative level of intensity. The second problem that needs to be addressed at Alliance level is the ability to organize "snap" military maneuvers without notice. In December 2014, Moscow launched an unexpected exercise in Kaliningrad Oblast involving 9,000 troops without notice. $^{38}$ By demonstrating its ability to mobilize such a large number of men so quickly, Moscow keeps the concerns of Central European nations running high in terms of the risk of a limited strike against their territories. While NATO is keeping its transparency policy vis-à-vis its military exercises, given Russia's no-notice approach, Alliance authorities should decide to organize similar activities, and, if necessary, conduct them as a deterrence measure.

\section{Empowering SACEUR to Speed Up Force Reaction Times}

The flash annexation of Crimea showed the world that signs indicative of a conflict or crisis might not be recognizable in advance. Furthermore, every NATO response decision relies on the consensus of its members, which in turn need time to debate and reflect. As a result, NATO must improve its decisionmaking process, at least on an operational level. Although SACEUR has been granted the authority to initiate the preparation of VJTF deployment, the

37 "Department of Defense Press Briefing by Gen. Breedlove."

38 Ian J. Brzezinski and Nicholas Varangis, "The NATO-Russia Exercise Gap," Atlantic Council, February 23, 2015, accessed July 17, 2016, http://www.atlanticcouncil.org/ blogs/natosource/the-nato-russia-exercise-gap. 
movement of troops still depends on NATO's political authorities. To face this issue effectively, and speed up force reaction times, NATO nations should agree to give SACEUR more powers, flexibility, and responsibilities. SACEUR should not only prepare and activate Allied reaction forces, but also deploy them in NATO's theater of war, if necessary. Granting permission of this nature might support NATO's deterrence posture as well as have the expected effect in the initial phase when a crisis breaks, ${ }^{39}$ and may let reaction forces act more preventively to avoid a situation whereby they are bogged down in a battle with no better operative options. ${ }^{40}$ Ultimately, NATO's political authorities should give SACEUR power to conduct “snap" exercises as a deterrence tool.

\section{Intensifying Military Cooperation with Non-NATO Baltic Countries}

NATO partners Sweden and Finland make a valuable contribution to the Alliance. Both nations' armed forces have an impressive background in terms of cooperation and a relatively high degree of interoperability with NATO. Sweden has contributed its forces to Afghanistan and its air component to Libya. Its forces have been taking part in the NRF. The same is true of Finland: its forces have participated in NATO-led operations in the Balkans and Afghanistan. In 2012, Finland also launched its troops' contribution to the NRF. Both also share various multinational security and defense projects and they are equally concerned about Russia's military resurgence. Therefore, NATO must maintain strong relationships with both nations in terms of exercise, training sessions, and building capability. NATO should improve both nations' processes of information and intelligence-sharing, and leverage the current level of operational awareness. In terms of combined capability-building, the allies should put the emphasis on developing assets such as intelligence, reconnaissance and surveillance, electronic warfare, and precision engagement. NATO also needs to heighten cooperation with regard to issues such as countering propaganda, disinformation, cyber defense, and strategic narratives.

\section{Leveraging Comprehensive Cooperation with the EU to Cope with $\mathrm{Hy}$ - brid Threats}

It is impossible to strengthen NATO's eastern flank, strategically speaking, without the involvement of the EU and its Common Security and Defence Policy. As a result, the NATO Summit in Warsaw should not overshadow the importance of the European Council meeting due to take place in June 2016 that will determine the future direction in which EU security and defense policy is headed. These two strategic security components-the EU and NATO-have to

39 Sidney J. Freedberg, Jr., "Wargame Warns NATO Unready for Baltic Crisis," Breaking Defense, April 12, 2016.

40 Tomasz Kowalik, "NATO on the Right Path from Assurance to Deterrence," The German Marshall Fund of the United States, December 15, 2015, accessed July 17, 2016, http://www.gmfus.org/blog/2015/12/15/nato-right-path-assurance-deterrence. 
mutually reinforce and complement each other in terms of actions, procedures, structures, competences, and capabilities.

A new EU Global Strategy should emphasize integrated, comprehensive, and synchronized cooperation with NATO with an emphasis on how to cope with hybrid threats as well as how to respond to the refugee and migrant crisis. In December 2015, NATO drew up an anti-hybrid strategy to enable it to respond effectively to a non-linear attack. The Alliance is currently developing a comprehensive set of specific early warning indicators that can trigger a number of different types of crisis-response options. ${ }^{41}$ NATO should invite the EU to be part of this work in order to share knowledge, experience, and best practices. This cooperation has to set itself apart by addressing non-military elements such as business, finance, media, cyber, or energy - all of which are important issues that may by impacted by a hybrid attack. Both organizations have to emphasize the importance of cyber security, strategic communications, border control, enhanced information and intelligence-sharing.

While the West seems unable to offer a strategic narrative that is as convincing as those presented by its opponents, ${ }^{42}$ the EU and NATO must unite their unique capabilities and start dispelling disinformation and propaganda, as well as exposing the lies and myths that confuse public opinion, aggravate social tensions, and undermine the trust put in governments.

\section{Showing Full Solidarity with the Southern Flank}

It is the obligation of NATO's eastern members to show the other Allies that security cannot be achieved on their territory without peace and stability in the southern section of the Alliance or in other parts of the Euro-Atlantic area. Even though the very existence of these nations is under threat from Russia, they should still mobilize themselves to ensure the security of the nations on NATO's southern flank. Especially as current trends suggest an increase in the numbers of refugees coming to Europe, these nations must be ready to back the stabilization efforts in southern Europe, support anti-ISIL coalition campaigns, and ultimately support Turkey's security, should this be unexpectedly required.

\section{Accomplishing the 2 percent Defense Spending Pledge}

The decision was made in Newport to halt cuts in defense spending and gradually increase its level to the expected 2 percent of GDP over the next decade. However, this decision has only gone a small way towards meeting the objective. Although twenty-one Allies halted or gradually reversed declines in defense investment in $2015,{ }^{43}$ one year on from the Wales Summit, up to ten na-

41 Jamie Shea, "Resilience: a core element of collective defence," NATO Review Magazine, accessed July 17, 2016, http://www.nato.int/docu/review/2016/Also-in-2016/ nato-defence-cyber-resilience/EN/index.htm.

42 Dempsey, "Is NATO Doing Enough in Europe?"

43 Statement of General Philip Breedlove. 
tions spent less than 1 percent of GDP on defense, and up to 16 nations spent 1.2 percent. At present, there are only five NATO members meeting the 2 percent benchmark (Estonia, Great Britain, Greece, Poland and the US).

It therefore seems unlikely that more than half of NATO's members will double their defense budgets over the next decade even if it is assumed that the current unfavorable security conditions in Europe remain. The failure to comply with the 2 percent defense spending threshold could have strategic implications for the future of the Alliance. In the short term, this could further irritate the US authorities and interfere with RAP operationalization. In the long term, it could affect, and even reduce NATO's political-military ambitions and significantly restrict the execution of the Alliance's full mission spectrum. Eastern NATO members, and in particular those demanding that NATO build permanent garrisons on their soil, should lead by example for the rest of the Alliance by meeting the 2 percent demand.

\section{Resume Constructive Dialogue with Russia}

Relations between the West/NATO and Russia are currently treading on thin ice, risking progressing from hybrid warfare to limited conventional warfare. ${ }^{44}$ To stop this process, NATO must engage with Russia in constructive dialogue. By virtue of its engagement in the Syrian conflict, Russia has managed, to some extent, to break free from its position of international isolation. By securing itself a crucial role in the process of resolution of the Middle East conflict, Moscow has managed to get a foot in the door to normalize relations with the West. Despite NATO Secretary General Jens Stoltenberg's assurance that there is little chance of a return to "business as usual" in terms of cooperation with Russia, $^{45}$ the last NATO-Russia Council meeting of April 2016, after almost two years of silence, signals that NATO wants to resume political dialogue with Moscow. However, it should be noted that such negotiations make sense only if NATO conducts them from a position of strength. Moscow will always see diplomacy without deterrence as the weakness of NATO/the West, thus encouraging the Kremlin to continue its neo-imperialist behavior. As a result, NATO must continue strengthening the Alliance's military presence on the eastern flank, while at same time engaging diplomatically to find solutions to implement the Minsk Protocol in full, to improve military transparency, and to reduce potential military risks.

44 Frank Hoffman, The Contemporary Spectrum of Conflict. Protracted, Gray Zone, Ambiguous, and Hybrid Modes of War (Washington, D.C.: The Heritage Foundation, 2016), accessed July 17, 2016, http://index.heritage.org/military/2016/essays/ contemporary-spectrum-of-conflict/.

45 Martin Banks, "'Business as Usual' With Russia Unlikely, NATO Leader Says," DefenseNews, April 11, 2016, accessed July 17, 2016, http://www.defensenews.com/ story/defense/policy-budget/policy/2016/04/11/business-usual-russia-unlikely-natoleader-says/82902184/. 


\section{Conclusions}

Strengthened NATO Response Forces and a more powerful Allied presence, created through the establishment of a rotational multinational brigade-sized component supported by scattered command centers on NATO's eastern flank, only go so far in terms of safeguarding the security of the easternmost parts of the Alliance. Russia's current policy trends and the ratio of forces in the region leave no option but to assume that there is still a very high probability that Moscow will continue to seek ways, including asymmetric methods, in which to breach the international security mechanisms put in place by NATO and the EU to guarantee today's stability in the Euro-Atlantic region.

NATO must continue with its process of strategic adaptation: its adversaries' abilities to adapt permanently and skillfully to the new security conditions, as their ceaseless tendency to test NATO's credibility leave no other course of action. To begin, the Alliance must leverage its internal solidarity and strategic empathy to offer intra-Alliance reassurance. It should develop a two-pronged deterrence strategy based both on punishment as well as denial. It must continue beefing-up ground forces in the Baltic region to total of two rotational combat-ready brigade-sized components, with the long-term objective of having at least one brigade permanently stationed in the Baltic states. It should establish air dominance over the Baltic region and improve HNS infrastructure to enable to absorb massive re-enforcements from the Allies swiftly. NATO must grant SACEUR new powers, namely in terms of speeding up force reaction times and conducting no-notice exercises, to ensure NATO forces remain responsive and its deterrence posture remains strong. In the international arena, the Alliance must intensify its military cooperation with non-NATO Baltic countries and intensify its comprehensive cooperation with the EU to enable it to cope successfully with hybrid threats. NATO members on the eastern flank must show complete solidarity with NATO members on the southern flank that are currently suffering from the ongoing migration crisis. All nations must show their commitment to reaching the 2 percent defense spending obligation. Finally, NATO must resume and conduct constructive dialogue with Russia with the aim of deescalating the current security situation. All these directives may contribute significantly to ensuring that NATO maintains an effective and credible deterrence posture, and, by extension, to increasing the probability that Europe's future will see greater security certainty.

The upcoming Warsaw Summit must, therefore, be seen as merely the end phase of NATO's long-term process of adapting to the new challenges currently posed by the aggressive military resurgence of the Russian Federation. The Alliance must constantly be evolving: action-reaction-counteraction must continue in an endless cycle. As part of this strategic process, NATO must permanently evaluate its policy, strategy, structures, capabilities, and forces. The strategic shift from reassurance, to reinforcement, to deterrence, launched at the Wales Summit, must continue even after the Warsaw Summit is over. 
NATO's Strategic Adaptation to the Russian Resurgence on Europe's Eastern Flank

\section{About the author}

Colonel Mariusz Fryc, Ph.D., is currently serving as the Deputy Chief, Military Analysis Branch, Armed Forces Oversight Department, National Security Bureau in Warsaw, Poland. 